\title{
LXXXIV. On the geology of east Norfolk; with remarks upon the hypothesis of Mr. Robberds, respecting the former level of the German Ocean
}

\author{
R.C. Taylor Esq. F.G.S.
}

To cite this article: R.C. Taylor Esq. F.G.S. (1827) LXXXIV. On the geology of east Norfolk; with remarks upon the hypothesis of Mr. Robberds, respecting the former level of the German Ocean , Philosophical Magazine Series 2, 1:6, 426-433, DOI: $10.1080 / 14786442708674356$

To link to this article: http://dx.doi.org/10.1080/14786442708674356

曲 Published online: 10 Jul 2009.

Submit your article to this journal $[\pi$

山 Article views: 3

View related articles 
or doctrine concerning it. On the contrary, it is indispensable for us to be acquainted at the same time with all the organs and viscera through which it circulates, as to their functions and actions; with the principles and elements of the physical sciences, and with those pathological facts which make up our knowledge of disease, or with the effects induced on the body by disease. And not only so, but we ought likewise to keep in remembrance the vicissitudes and changes of state which are induced on the body by numberless external and internal influences, whether by climate, seasons, states of the weather; or by diversities of food, medicines or the like; or by passions of the mind, which may be either in an orderly or disorderly condition :-in short, the circuit of science in its widest range; its height and its depth, must all be searched, in order to arrive at a complete knowledge and doctrine of the blood.

It will not be difficult to discern, therefore, the reason of our comparative ignorance, and of our real uncertainty concerning its true nature; for in proportion to the limited views we take of this wonderful fluid will our means fail us of escaping from the labyrinthian windings of the subject, or of extricating ourselves from those difficulties respecting the nature of life which the materialist delights in on the one hand, and the mystic broods upon on the other.

In our next lecture we shall proceed to consider the Fluidity and Vitality of the Blood.

['To be continued.]

LXXXIV. On the Geology of East Norfolk; with Remarks upon the Hypothesis of Mr. Robberds, respecting the former Level of the German Ocean.By R. C. TAYLOR, Esq. F.G.S.

[Concluded from page 353.]

THE ground upon which the town of Yarmouth stands is decidedly alluvial. Four distinct processes contributed to its formation. The first may be traced in the accumulation of heavy materials, rolled by the action of the sea; the second in the deposit of oozy sediment from muddy waters; the third in the external covering of sand by the operations of the winds; and lastly, in the rise and decay of vegetable substances.

The wind is a more powerful agent in forming the sandy belts which defend our shores, than has been imagined. $\mathrm{Mr}$. Robberds has overlooked this circumstance altogether, in speculating on the origin of the low lands between Caister and Gorleston. His arguments are, that if the sea retained the same level as when it washed up the banks across this æstuary, it would occasionally still overflow those mounds; and 
its waters would be capable of sweeping away at one time, what they may have brought at another; for "it is physically impossible that water, even in a state of the most impetuous agitation, should raise any permanent barrier against its own course."

It is no less singular than true, that in the whole circuit of our shores, wherever the substantial barriers of high lands, cliffs and rocks are wanting, except in the cases of retiring unexposed inlets, nature has substituted defences of sand, accumulated by the winds, preserved by peculiar plants, and rarely requiring the assistance of man to render them effectual.

Has Mr. Robberds never rambled by the side of the sandhills, formed by the actions of the winds, along the coast between Winterton and Happisburgh; or witnessed the remarkable ridges of sand, provincially termed Meals, by which the harbours of Cley, Blakeney, Wells, Burnham and Brancaster, are securely defended from the fury of the northerly gales? These hills are 50 or 60 feet high; they are composed of dry sand, bound in a compact mass by the long creeping roots and fibres of the plant called marram:-Arundo arenaria*. To this singularly useful plant the sand-hills owe their consolidation and elevation; it has been cultivated with some care upon our coast, and the industrious Dutch are indebted to its assistance for the preservation of their islands and flat coasts.

On the western coast, where the tides attain a great elevation, the marshes of Pembrey in Carmarthenshire have four or five concentric ridges of similar hillocks, forming as perfect and permanent barriers against the sea as the art of man could execute.

The mouth of the River Ogmoor, in Glamorganshire, presents a singular appearance of desolation at the present moment, through the agency of the wind and sand. Its ancient channel is filled up for two miles; houses are rendered uninhabitable, and sand-hills are raised nearly 150 feet. The mountains which bound the harbour will check the advance of this sand-flood into the interior; otherwise it threatens to overwhelm all the lands which adjoin it; while the squalls of wind, rushing down the steep valleys, occasion eddies, which deposit the sand at an elevation apparently far beyond the reach of such an irresistible enemy.

There is no need to multiply instances; and having men-

* "One of the most valuable grasses for binding the sand of the seashore, and raising those banks which in Norfolk, and especially in Holland, are the chief defences of the country against the encroachments of the ocean. Elymus arennrius, Carex arenciric, and even Festuca rubra, contribute to the same end."' Smith's English Flora, vol. i. p. 17\%, 


\section{Mr. R. C. Taylor on the Geology of East Norfolk.}

tioned these, out of many of a similar description, the comparatively insignificant height to which the sand has hitherto been drifted on Yarmouth Denes (dunes or downs), will scarcely be considered deserving further discussion. At all events it may be stated, since the fourteenth century the operation has proceeded unceasingly, and may at a future period become a formidable evil to that town. It is an historical fact, that part of the ground within the limits of the Burgh is artificially raised. The ramparts round the inside of the walls were constructed in 1663, from " those little sand-banks which the sea and easterly winds had raised on the denes."

It is a well known fact, proved before a committee of the House of Commons during the last and present session of parliament, that the chief portion of the eastern marshes is even now eighteen inches to two feet below the surface of the rivers which pass through them, and that the water is artificially kept out by embankments and draining mills. Consequently; were the operations of these to be suspended, the valleys would, even under the present circumstances as to the admission of tides, be overflowed about the same depth as the unembanked Lake of Breydon.

All the tidal waters that proceed up the various streams and diffuse themselves over Breydon Lake, must previously pass through an opening or water-way only about 150 feet wide at Yarmouth bridge; and such are the obstructions so narrow a passage and the bar present to the ingress of the tide, that an eminent engineer has recently reported that the height of highwater above Yarmouth bridge is from one to three feet lower than at the haven's mouth. The average rise of the tide throughout the year at Yarmouth bridge being only three or four feet, the absolute quantity of sea water passing into the interior is therefore very small.

Let us contemplate the effect produced, when an immensely increased volume of water pressed forward, unimpeded, through several wide openings, as in the former state of the Saxon shore. It would be contrary to all analogy to assume that these inlets ever existed upon such an exposed coast, and amidst such moveable materials, without bars at their mouths, like the deep Forths of Scotland, to which they have been improperly assimilated. Nevertheless, a large body of sea water would advance, and be forced, in proportion to the width and depth of those openings and the absence or presence of obstructions, more or less far up the valleys. 'The waters of wide æstuaries being impelled by the force of the tides from behind, and being restricted in their channels as they proceed by the contracting high grounds, actually attain a considerably 
Mr. R. C. Taylor on the Geology of East Norfolk. 429

higher elevation than the open sea whence they proceed. On the contrary, in narrow entrances, like the haven of Yarmouth, the tidal waters speedily sustain a material decrease in their height; and in this instance, we have seen that the level of Lake Breydon is from one to three feet lower than the ocean, from which it is separated by an alluvial bank not half a mile across. If to the thickness of the bed of ooze be added the difference between its present surface and that of the sea at high tides, we obtain the absolute depth of water which could with any probability be contained within the æstuaries, at the earliest period, before they received any portion of their covering of marine sediment. But there appear no conclusive reasons for assigning a higher level than four or five feet above the mean height of the existing rivers, at any period of which we possess historical records.

Surely Mr. Robberds's etymology of Herringloy and Herringfleet is explained to favour a given theory, and must be received with caution. One at least is an evident comption of compound Anglo-Saxon words, and has no reference to fish, whose habits lead them to avoid shallow muddy rivers. In Domesday Book, Herringby is written Har-ing-bei. Herringfleet is spelt Herl-yng-flete; and in a subsequent record we have it Herl-inga-flet : the two first syllables being clearly the same as Herling, lately written Harling, in Shropham hundred.

About the year 901 the boundaries of the counties and hundreds were defined, and the limits of parishes and manorial jurisdictions were determined. These provincial subdivisions, and even the estates into which they were further appropriated, are carefully registered in Domesday Book. It happens, without any exception, that all the boundaries of the connties, hundreds, and local jurisdictions of this district, are the rivers which wind through the various marshy valleys. It follows, therefore, that these streams had, as early as the year 900, formed themselves channels, adapted to mark the boundaries of property; which channels have continued to our times, with little alteration, except at their immediate outlets.

They were gradually embanked, as cultivation proceeded and the value of land increased. We know that the river which divides the hundreds of Flegg and Happing was embanked previously to 1274, near the Abbey of Holm; for in that year occurred a dispute about the right of fishing from the river's banks.

One mode of estimating the comparative elevation of the waters, is distinctly furnished in the causeways or dams, which were early constructed across the restuaries. The bridge call- 


\section{Mr. R. C. Taylor on the Geology of East Norfolk.}

ed Weybrigg, at Acle, and the great causeway connecting with it, were certainly in existence in the eleventh century; and we find that payments were made towards their repair in 1101, and succeeding years. This causeway is so little above the present level of the river and marshes, that even in our own times it has been repeatedly overflowed. At any rate, it establishes the negative fact, that no very important change has taken place in seven centuries at a point adjoining the broadest part of the main restuary, and only eight miles from the sea.

It is stated in a preceding page, that to a limited extent the channels of the Yare and other rivers were wider than at present; evinced by the peaty margins and the deposit of silt in the undisturbed recesses. 'These circumstances are confirmatory of the reduced supply of tidal waters, and show that the streams have gradually accommodated themselves to the volume of water which they have to convey.

With regard to the arrival of the Danish fleet at Norwich, A. D. 1004 , no other change is needed to explain the probability of such an event, than has been accounted for. At that early period of the art of navigation, ships were constructed of little burden and of light draught; and with the advantages of several feet of tide, there could be little bazard in attempting a navigation which even at this day is capable of admitting the smaller description of coasting vessels. Nor could there be much danger under the circumstances, in an enterprize where there was neither a hostile fleet nor army to contend against; and where, on arriving at the capital of East Anglia; the invaders found the inhabitants unprepared for defence, and eager to purchase an humiliating peace.

The Salinc, mentioned in Domesday Book, were chiefly situated on the north shore of the main zestuary, within three miles of its mouth; 39 of them being at Caister, and 30 more in the two contiguous parishes. None occur in the Norwich, Beccles, or Kirkley valleys; and as it does not appear that saltworks were mentioned after the Confessor's time, it is probable that the north entrance commenced silting up shortly after, so as to exclude the requisite admission of sea water for such works*.

Some uncertainty prevails with respect to an open communication between the ocean and the extensive watery flat near Horsea. Mr. Robberds's map shows two points by which the sea appears to have penetrated into this flat. Local records are silent upion that head. There is no mention of saltworks

* The value of a Salina was at that time extimated at sevenpence. 
upon its borders, or of any other circunstances positively implying such an event. From the remotest period to which we can refer, it has been a branch of the main æstuary of the Garienis, and by this channel the drainage of the district is effected. The soil is composed chieity of peat, rather than of ooze; the first characterizing the upper parts of a valley, the latter its mouth. Whether by the gradual external wearing away of this coast, the sea approached so near this flat as occasionally to overflow the intervening bank of sand; or whether that bank results from the abrasion of the cliffs to the north, and blocks up an ancient inlet,-there are scarcely sufficient data to determine. The existence, therefore, of those northern channels, although not improbable, must remain conjectural.

There is a mistaken quotation at p. 66, stating that, A. D. 1549, an armed pinnace was sent up the Waveney, as far as Weybread. As the place is called Waybridge in the original authority, this evidently refers to Waybridge, netr Acle; that being the most important pass between Yarmonth and Norwich, near which place the rebel arny was encamped. Weybread in Suffolk was far removed from the theatre of operations, independently of the physical improbability of any vessel ascending this stream, at least 40 feet above the level of the Yarmouth river, and of passing half-a-dozen water-mills, which interpose in its course. It would not have been necessary to notice this error, but for the circumstance of its being classed with proofs of the aliftude of the water, as late as the sixteenth century.

No further comments are suggested by the historical evidence adduced to corroborate the physical circunstances that have previously been investigated, to sustain the theory of an extraordinary reduction in the level of the waters of our æstuaries, and by inference, in that of the surrounding seas.

The result of the foregoing inquiry is opposed to that hypothesis. This inquiry suggests views of cause and effect adequate to the admitted extent of the change, which are briefly these :-

That as-long as the ocean-currents set unrestricted into these estuaries, it was in sufficient quantity to expand over and fill them; the elevation being limited by the height of the tides at the time, and the depth by the greater or less accumulation of oozy sediment.

That there was from the remotest period, through the local causes which have been detailed, a progressive decrease in the volume of this water, and by consequence a reduction, in an equal ratio, of the power to maintain an open mouth. 
That the same causes which finally closed the astuary at Caister, were simultaneously operating to bar the ancient haven at Kirkley, and probably to exclude the sea from the more northerly inlets.

That as soon as the admission of the tide was limited to one narrow and obstructed inlet, the quantity thenceforward was so trifling that "many thousand acres became dry, and in time good pasturage for cattle." With the assistance of embankments, the entire level of marshes became firm land; rich vegetation covered its surface, and the rivers were restricted to their deep channels.

This is the solution of that change whose traces are yet so perceptible; a solution compatible with all the real circumstances, physical and historical, with which the subject is connected. Whilst care has been taken to divest the recital of its apparently exaggerated features, abundant range has been allowed, in accordance with physical probability, for all recorded facts and fairly inferred occurrences.

There exists nothing in the series of phænomena, displayed within the limits of these eastern valleys, that is not repeated on a tenfold scale, in the fens of Lincolnshire and Cambridgeshire. We have there the spectacle of a tract as extensive as the county of Norfolk; once an inland sea, now valuable and productive land;-subjected, in its various stages, to operations similar to those on the shores of the Garienis :-reclaimed, abandoned to the ocean, and again reclaimed;- - while the efforts of nature in this earth-forming process, seconded by the labours of man, have been recorded with instructive fidelity.

Assumptions founded on the limited considerations of local operations, of obvious origin and of daily occurrence, are objectionable, because the deductions drawn from thence are seldom applicable to general principles.

The filling up an astuary by the gradual precipitation from waters charged with alluvial mud, and the consequent exclusion of the tide from its ancient receptacles, offers no better claim on which to establish the principle of a general depression of all the seas in this quarter of our globe, than the actual elevation of several feet, through obvious volcanic agency, of the bed of the Pacific Ocean for a hundred miles parallel to the Andes, proves the general depression of the entire waters of that immense ocean.

The antediluvian shells in the margin of the Norwich valley, prove a local formation only; not the general elevation of the North Sea, subsequent to the deluge. As well might Mr. Robberds have fixed the general elevation of the mighty 
waters at that point on the Apennines, where are deposited the Buccino, the Turbines, and Murices, of which analogous genera are so abundant at Bramerton: or have ascended the scale, and carried its limits yet higher,-where, at the height of twelve hundred toises, upon the Andes, M. Humboldt discovered the fossil teeth of the mastodon, whose remains are also found with the crag shells in our humble valley of Norwich.

It was the common error of the English geologists of the last century, to deduce consequences from too limited premises. Thus our Whitehurst, Woodward, Whiston, Hutton, and other intelligent observers, had each his favourite theory: each saw in the phænomena around him sufficient confirmation of a preconceived hypothesis; each reasoned and speculated from the confined data which came under his own particular observation : and, as it happens in all those cases where research is limited to the evidence of peculiar systems, the facts were not always recorded so impartially as the strictness of geological inquiry demands. Thus, for a time, schools were instituted, the disciples of which saw only through the eyes of their respective masters, and rejected truths which harmonized not with their views. It is obvious that such a process tended rather to confuse, than to simplify and facilitate the progress of this science.

This disposition to theorize has happily decreased, as the number of observers has augmented; while all unite to collect the data, to arrange the documents, and to combine those proofs, whence hereafter will arise some incontrovertible and universally acknowledged principle, by which to account for phænomena at present so inexplicable.

LXXXV. A Synopsis of the Birds discovered in Mexico by W. Bullock, F.L.S. and H.S., and Mr. William Bullock, jun. By William Swainson, Esq. F.R.S. F.L.S. \& .

[Concluded from p. 369.]

Fam. Sxlviade.

G. Trichas. Srwains. in Zool. Journ. No. 10.

37. Trichas personatus. Sylvia trichas, Wilson i. pl. 6.f.1. Near Vera Cruz.

G. Sylvicola. Sreains. in Zool. Journ. No. 10.

38. Sylzicola pusilla. Wilson iv. pl. 28. f. 1.

Nero Serics. Vol. 1. No. 6. June 1827. $3 \mathrm{~K}$ 39. Sylvicola 